
Journal

9| 2014

Imagining Bangladesh: Contested Narratives

\title{
The State of Relief on the Bangladesh-India Border
}

\section{Delwar Hussain}

\section{OpenEdition}

\section{Journals}

Electronic version

URL: http://journals.openedition.org/samaj/3728

DOI: $10.4000 /$ samaj.3728

ISSN: 1960-6060

\section{Publisher}

Association pour la recherche sur l'Asie du Sud (ARAS)

\section{Electronic reference}

Delwar Hussain, «The State of Relief on the Bangladesh-India Border », South Asia Multidisciplinary Academic Journal [Online], 9 | 2014, Online since 22 July 2014, connection on 06 May 2019. URL: http://journals.openedition.org/samaj/3728; DOI : 10.4000/samaj.3728

This text was automatically generated on 6 May 2019.

\section{(c) (i) (9)}

This work is licensed under a Creative Commons Attribution-NonCommercial-NoDerivatives 4.0 International License. 


\title{
The State of Relief on the Bangladesh-India Border
}

\author{
Delwar Hussain
}

\section{Introduction}

1 The NGO phenomenon in Bangladesh began soon after it was founded in 1971 when international donors felt that the government had little or no capacity to efficiently process the development aid coming into the country. Donors thought funds could be spent less wastefully through such organisations. Today NGOs also fit into donors' new policy agenda of stressing good governance as well as the wider, long-term ideology of economic and social reforms. White (1992: 12) observes that at one extreme are the massive projects of multilateral and bilateral donors who strengthen the national infrastructure (roads, bridges or electricity) and at the other is the multitude of smaller organisations using foreign funds for the welfare or development of disadvantaged groups. Some of the latter organisations are in charge of neighbourhood development projects whilst others run massive enterprises and have (inter)national ambitions and reach. Some observers celebrate the roles NGOs play, seeing them as a crucial force for improving the quality of life of countless Bangladeshis. With the inability of consecutive governments to provide services (due to ineptitude and/or lack of resources), these endeavours, it is argued, contribute to the state's viability and stability (White 1992: 12-13). On the other hand, critics argue that the optimism that NGOs may help to decrease poverty has not proven to be justified. They say that the industry has propelled sections of the local middle classes into prosperity by providing jobs and access to resources, whilst the majority continue to languish at the bottom. Opponents also claim that the expansion of NGOs has advanced the 'retreat' or 'rolling back' of the state (Sobhan 1997, Rahman 1999), 'cut away ground from beneath a still-weak state', eroded public accountability and provided the loosely connected international aid community with the opportunity to intrude upon domestic policy (Lewis 2010: 10). Wood (1997) for example believes that Bangladesh is moving towards a 'state without citizens' in that, as a result of 
patronage relationships and structural adjustment policies, it has 'discarded' its responsibilities to its citizens for service provision. More than 30 years ago, Rahman Sobhan (1982: 226), a prominent Bangladeshi academic wrote:

The sovereignty of the Bangladesh nation state, in its prevailing social configuration, is therefore likely to remain a polite fiction which is perpetuated by the courtesy of the donors as long as Bangladesh does not challenge their current strategic assumptions and ideological preconceptions.

2 The pervasiveness of NGOs is part of the neoliberal state which operates by working alongside a myriad of non-state actors (e.g. aid organisations, volunteers, private companies, entrepreneurs, consultants, security companies) which together bring about and produce 'state-like' effects. In this way, the state, in its 'multiple incarnations' continues to be a powerful object of encounter even when it cannot be located as a unitary structure (Aretxaga 2003: 398). The idea of multiple governing agencies challenges the idea of the state as a single centre of power, and is an extension of 'governmentality'. Foucault's (2006) powerful statement goes beyond the more simplistic argument about the 'weakening' or 'eroding' of the state, and is a useful tool in analysing transformations of the state and how various, multiple forms of power are exercised. Foucault suggests that power has to be examined in a multi-dimensional form, taking into account factors such as economy, politics and history. The $18^{\text {th }}$ century saw the rise of a new type of sovereign power, he says, where the practices of government became 'multifarious and concern[ed] many kinds of people' (both internal and external to the state). This included a multiplicity of differing techniques of domination, discipline and regulation of bodies and populations, leading him to suggest that 'we find at once a plurality of forms of government and their immanence to the state' (2006 [1991]: 134). Foucault (2006 [1991]: 134) questions the notion of the (European) state (the archetypal model) as ever having been a unified, supreme container of power, or ever having 'this individuality, this rigorous functionality, nor, to speak frankly, this importance'.

3 Ferguson \& Gupta (2005: 107) extend this argument and formulate the idea of 'transnational governmentality' to view the contemporary changes being wrought to the state system, the core feature of which places the 'governing-practices' of subnational, supranational and other non-state institutions and actors within a single analytical framework. This means exploring the workings of the state alongside those of deterritorialised institutions of global governance such as the World Trade Organisation, the International Monetary Fund and World Bank, as well as those already mentioned. Corporate, globalised media and 'international public opinion' are also amongst this multiplicity of governing agents, all of which work alongside existing, localised actors. Rather than describing these global entities as being 'below', 'above' or even outside the workings of the state, Ferguson \& Gupta (2005: 121) say they are 'integral parts of a transnational apparatus of government' and components of an emerging system of transnational governmentality. ${ }^{1}$ The fusing of the local and global, they suggest, does not replace or necessarily challenge the older system of nation states, but it does transgress, disregard and 'decentre' previous understandings of the developmentalist state framework.

In this paper, I focus on a remote part of the Bangladesh-India border in order to understand how the state in its current neoliberal avatar, has been reconfigured from its older, developmental paradigm, which involved large-scale infrastructural change and resource redistribution. I describe how the state is now merely one of many other 
multiple governing agencies that participate in producing 'state-like effects' on a territory and its population. Sometimes these are in competition; often they work alongside one another. This understanding of 'state-like effects' is in keeping with Aretxaga's powerful argument that in the era of globalisation, practices of legibility and control are carried out by a variety of organisations and take a variety of forms that together produce 'state-like effects'. What this means is that the state has lost many of its ordering functions such as the organisation of health care, education, economic production, imprisonment and military and policing interventions, and that these functions and roles are now contracted out to private companies, aid organisations, NGOs, private entrepreneurs, security companies and warlords. As a result, the state continues to be a powerful object of encounter even when it cannot be directly located (Aretaxga 2003: 399). This paper is, then, an exploration of what 'state like effects' look like in a place such as the border between Bangladesh and India.

5 I begin by firstly providing an historical overview of the rise of NGOs in Bangladesh. I then draw out what the state attempted to be post independence through the example of a cross-border coal mining village called Boropani ${ }^{2}$ and its neighbour, a now defunct state-run industrial site. Known as the Khonighat Limestone Mining Project, it was built in the 1960s to furnish the country with limestone, but importantly it constituted a project of a different order: an ideal of the state in microcosm. Following this, using the example of a NGO relief programme, I show the blurred line between the state and the NGO sector. I conclude that regardless of who is performing state-like effects, vast numbers of people continue to be marginalised.

\section{History of Development}

6 The contemporary Bangladeshi state is a part of other governing agencies that produce 'state-like effects'. However, against some of the writers cited above (both supporters and critics of NGOs) who argue that neoliberalism alone has fractured the link between nation-states, sovereignty and territoriality, I suggest that post-colonial countries such as Bangladesh have always had mediated sovereignty. This is a phenomenon that has simply continued into the present to the extent that international donor agencies and regulatory authorities have almost as much authority as states themselves. In this light, Sobhan's forewarning above about international aid 'eroding' Bangladesh's sovereignty is misconceived. Bangladeshi sovereignty has always been at the whim of many centres of power. Even before 1971, when the country was established following an armed struggle against West Pakistan (East Pakistan later became Bangladesh), the centre of power/s were located elsewhere. Kaviraj (2000: 142) argues that in 'traditional subcontinental society,' political power was often distributed between several layers of authority stretching from the village, through regional kingdoms, to empires. From the Mughals, through to the East India Company and the British Imperial state, power lay in Delhi, Calcutta and London respectively. During the Pakistan period, economic and political clout resided in Karachi and Islamabad. Throughout and beyond the Cold War, Washington, Beijing and Moscow were crucial sites for the realities of East Pakistan. The Middle East is also key to this argument, with the majority of the country's population being Muslim, but also because a large amount of aid today comes from Saudi Arabia. The suggestion that Bangladeshi sovereignty is dissipated between different agents is not 
particularly new. What is, is the myth of wholeness itself and the idea of the unity of the country's sovereignty.

7 Sheikh Mujib (head of the Awami League party and leader of the party during the revolt against the Pakistani state in 1971) inherited, as Prime Minister of the new state, economic chaos that was partly a consequence of the systematic disadvantaging of the Eastern wing by the Western wing of Pakistan. ${ }^{3}$ The struggle for independence aimed to bring this disparity to an end. But the civil war and the resultant humanitarian crisis made the difficulties of the new country worse. Over $80 \%$ of the population lived below the poverty line (van Schendel 2009: 221). Critics on the left insisted that Bangladesh implement state socialism and land reform. The right saw the solution in economic liberalisation and support for the private sector (van Schendel 2009: 193). In keeping with its declared socialist principles of state capitalism (it received aid and support from India and the Soviet Union), the Mujib government nationalised industries, banks and commercial companies (Alam 1995: 95). However, these policies failed to make the industries profitable or pull the country out of a financial quagmire.

Dependence upon international funding from the 1960s onwards began to rise as western aid became easily available for newly decolonised countries. Institutions such as the World Bank and IMF became closely connected to the military dictatorship of Ayub Khan, which 'conceived and underwrote Pakistan's development strategy' (Alam 1995: 168). Despite concerns that foreign aid might compromise Bangladesh's independence, the Mujib government realised that it was key to its survival and as aid revenue grew massively in the early post-independence period, the country became a celebrated 'case of aid-propelled development' (Alam 1996). ${ }^{4}$ Thousands of foreign consultants, volunteers and diplomats descended on Bangladesh. Jobs were created for the new indigenous bourgeoisie in emerging NGOs and myriad development projects across the country.

Following Mujib's assassination in 1975, which Khan (2000: 581-582) attributes to his economic mismanagement, the country entered a long period of consecutive military dictatorships. From 1975 to 1990, foreign aid dependence went up further. This helped to prop up the dictators, but more saliently, brought about fundamental shifts in the country's economic policies, moving it away from its founding principles. International organisations such as the World Bank and the IMF induced the regimes to liberalise the economy, accelerate privatisation and undertake structural adjustment. The development strategies pursued under the General Zia and General Ershad regimes saw the unpicking of policies laid down by Mujib. Neoliberal reformers envisaged that such steps would resolve the symptoms of the post-independence crisis.

It is at this point that the growth in NGOs began; there was real optimism that they would solve many of the country's problems. Here, a comparison with the past is illuminating. There were many international NGOs carrying out relief work in the country during the crisis of the early 1970s, but relatively few indigenous ones were established. This is because, as Hasan says, there was anticipation that the government would look after rural people (Hasan 1993: 94, Lewis 2004: 307, see also Feldman 1997). This point is crucial in appreciating what was anticipated. The state gradually became unable to deliver rural or urban development and the hopes raised first in 1947, and then in 1971, were unrealised. Consequently, as Lewis (2004: 307) observes, activists and social entrepreneurs began to search for new organisational structures with which to address public problems (as well as to build personal careers) and the boom in indigenous NGOs began. 
10 The programme of economic liberalisation initiated under Generals Zia and Ershad's dictatorships has accelerated since the establishment of democracy. The first democratic government in 1992 also continued the privatisation of the public sector and lifted market restrictions. Institutions that were seen to distort market outcomes, facilitate collective action and centre on a planned economy, labour relations and social policy were targeted and dismantled (Taylor 2009: 29-30). Ferguson (2006: 12), writing about African states, but applicable to Bangladesh, says that the promise of democracy was held out to the citizenry at the precise moment that crucial issues with regards to the economy were taken out of the hands of national governments. Democracy, he argues, became a way of cynically attributing blame to national governments (and by implication to voters themselves) for economic failures. At the same time, matters to do with the policies of donors were taken out of the realm of representative democracy.

\section{Background to the Border}

11 The village of Boropani was divided in two at Partition in 1947. Today it is at the centre of the cross-border coal trade between India and Bangladesh. The mines are all on the Indian side in the West Khasi Hills and the labourers are mainly from Bangladesh 'illegally' crossing the border to work in them. The state in Bangladeshi Boropani is represented by the Customs House at the Zero Point and the rotating contingent of Bangladesh Rifles guards who are charged with protecting the border. The concentration of these categories of employees / institutions in the area indicates the state's concerns and interests at the border: primarily to generate profit from and maintain its authority through sanctioning cross-border activities. This feature of the margins of Bangladesh and India has not altered since the formation of the new states and, if anything, has been exacerbated since then. Vote-garnering political candidates make occasional visits. The nearest bank, police station, and health facilities are some hours away in the headquarters of the district subdivision in which Boropani is located. Sunamgonj town, the district's main administrative centre, is around six hours away by boat during the wet season and at least two by motorbike when dry. Locals forced to take their ill family members on this arduous journey may have to go to Sylhet town, a further two hours away. It is usually the more affluent and the most desperate who carry out this expedition.

Yet the reasons for the lack of the state here are more complicated than Ong's assertion (2005: 95) that there is a 'thinning of state power at...border zones'. Across Bangladesh, the state is thinned out. In this regard, there is little difference between border and nonborder areas. However, in Boropani, present realities are in contrast to what previously existed here. The developmental trajectory that newly independent, post-colonial states followed in the mid-20 $0^{\text {th }}$ century is writ small here. In the 1960 s a limestone quarry was built next to Boropani as part of the newly decolonised country's attempts at modernisation. The aim of the Khonighat Limestone Mining Project was not simply to extract limestone, though this was of course one of its core functions. During its operation, it was at the centre of a much larger, protracted utopian goal that constituted a project of a different order (see Hussain 2013 for a more detailed exploration of the workings of the Khonighat Project). Within the perimeters at least, the 'corporeal presence of the state [wa]s potent' (Roy 1994: 105). As an inciter of modernity, it was to re-write history, question old structures, banish 'backwardness' to a distant past and be 
at the forefront of the new world order for everyone and everything that came into contact with it. Project workers and their families who came to live and work in this remote part of the border were to be part of the modern industrial workforce but more importantly, contemporary and enlightened citizens of the new modern state. They had access to healthcare, housing, electricity and educational facilities.

Modernisation, the theory and practice, dictated that once peasants make the move from working in the field to the factory, these so-called 'backward' people would be propelled into 'civilisation' and the future. By following this process, poor countries would overcome poverty, share in the prosperity of the 'developed' world and take their place as equals in a worldwide family of nations (Ferguson 2006: 177). The idea was that the state was at the centre of development programmes, preoccupied as it was with national progress or, in other words, the development of the whole. Therefore, along with import substitution and backing private entrepreneurship, state-led development concentrated upon spectacular public works. Entire cities, such as Brasilia (Brazil), Islamabad (Pakistan) and Chandigarh (India) were carved out where none existed previously. More commonly, this involved building infrastructure (roads, bridges), developing large-scale power projects (hydroelectricity dams, power stations), constructing industries (manufacturing, refineries, factories) and civic institutions (courts, hospitals, schools, universities, libraries, parliaments). Most of this was concentrated in urban centres, but 'unknown', so-called 'peripheral' places (such as the region where Khonighat and Boropani are located) were also targeted.

The Project was closed down in the 1990s largely due to corruption, but also because of neoliberal machinations at a grander scale (see Hussain 2013). It now lies in spectacular ruin, a stark contrast to what it had attempted to be, the developing state in microcosm. It is no wonder that the few remaining Project residents feel an acute sense of abandonment and rejection when recalling the past. Nonetheless, what is worth keeping in mind is that those who did not work for the Project, or lived outside of it in Boropani, were unable to access the services it provided, so for many little has changed over the years. ${ }^{5}$ Of course Bangladesh (or the Pakistani state previously) was never a welfareheavy state as were/are the UK or the former USSR, for example. Neither was it ever in a position to provide services for the majority of its citizenry. To argue, then, that in the neoliberal era, the Bangladeshi state has retreated, as many observers have done, is inaccurate. Modernisation schemes were always exceptional. This is what made the Khonighat Project so extraordinary and its visions so powerful for all those who came to live and work there. Today the single, unitary idea of the state has become a rumour for remaining Project residents (who thought they knew better) and recent migrants to Boropani alike. Many people here have little to do with the reduced icons of the state that do exist. While these are generally people at the very bottom of the social and economic hierarchy, coal importers and depot managers also complain about the lack of facilities in the area. The argument they put forward for wanting greater state presence justifies their evasion of taxes on the coal they import. One such businessman explains:

The government makes lakh lakh Taka from us [the coal industry] but would you be able to tell what they have provided in return? The answer is no, nothing. There is no school, no pucca road, nothing. I can afford to go to Sylhet when ill and send my children there to be educated. But, tell me, what about the poor? What are they to do? Tell me, what is the point of paying taxes? ${ }^{6}$

In Boropani, NGOs delivering services include BRAC: the second largest employer in the country after the government (Lewis 2010: 9), ASA (Association for Social Advancement), 
Sancred (a Norwegian organisation closely related to the Lutheran church) and also a smattering of very small, grassroots, locally-focused organisations that specialise in the wetland region. Sancred members are seen by a doctor for a 20 Taka fee (roughly 20 pence) for which they are examined and provided with prescriptions. The cost of medicine is extra and those requiring more complicated procedures are sent to Sunamgonj. BRAC offers loans to purchase solar power facilities as well as general business loans. One organisation brings a vet from Sunamgonj a few times a month to treat livestock belonging to members. All of them specialise in microcredit programmes, which is how they fund the services they provide. Locals do not remember precisely when NGOs began arriving in the area, but some say Sancred was the first to set up its offices outside of the perimeters of the Project. A neighbour remembers seeing a white woman whom people believed to be a Christian missionary. Apparently her presence was not welcomed by locals who would throw stones at her. The arrival of the NGOs in the area in the 1990s coincided with the closure of the Project, the opening up of Bangladesh and India's markets and the beginning of the abdication by the state of what many in the borderlands had come to expect from it.

\section{Relief}

16 It is the monsoon season. I am invited by Tariq, a local friend who works for an NGO, to accompany him on a relief programme that is to take place in the wetlands that surround Boropani on the Bangladeshi side. Tariq works for a large European NGO, which I call Hands Together, ${ }^{7}$ based at its regional office in Sunamgonj. Hands Together runs a number of programmes throughout Bangladesh, one of twenty countries it works in. Tariq is in charge of coordinating the relief and I am joining him on the day corrugated tin is being handed out. I am keen to observe this ritual. Crucially, it is from isolated villages such as the one we are to visit that the majority of the seasonal and temporary coal labourers in Boropani that I had hitherto been working with, originally came from (see Hussain 2013). When the waters of the monsoon take over their rice fields, men, women, and children migrate to Boropani and devote themselves to coal extraction. At least some of the money earned in the cross-border coal trade between Bangladesh and India comes back to villages such as this.

17 In 2007, a flash flood destroyed large numbers of homes in a particularly isolated part of the wetlands. Today's relief-NGO jargon for the distribution of aid materials-is a one-off event to be carried out in a village in which one of Hands Together's local partners, a grassroots, community-based organisation which I call NAT, has been working for some years. NAT specialises in development projects in the wetland region. ${ }^{8}$ The schemes it runs include setting up shomithis (committees) to which it provides ideas and logistics for income generation. But it is microfinance that it is principally concerned with. Affected villagers that NAT work with are to receive building materials, as well as ducks and goats. All of this is funded by Hands Together.

On the back of Tariq's Indian Hero Honda motorbike, we follow the now disjointed and broken railway tracks that lead from Khonighat to Poschim Bazaar. When the state-run installation was still in operation, the limestone from the quarries in Khonighat was transported to Poschim Bazaar, uploaded onto barges, and sent to the headquarters where it was processed into cement. No longer with a role to play in the modernisation of cities elsewhere, today Poschim Bazaar looks as forlorn and stranded as Khonighat. With 
no sign of a boat that will take us to the village, Tariq confides that he is nervous about the distribution. Heated words have already been exchanged between Hands Together's regional office in Sunamgonj, the community-based organisation NAT, and the villagers expecting relief. Apparently, the list of names that was originally drawn up-of people who are to receive the building materials and livestock, supposedly the most severely affected by the devastation in 2007-had to be re-done. According to Tariq, NAT employees had filled it with names of their own relatives, denying those who are the neediest. The Sunamgonj office learned of this and instructed NAT's staff to re-do the list, threatening to deny them any future project work and funding if they do not comply. The second list that was drawn up has a different set of names, but, as Tariq explains 'there is no way of checking the validity of the revised list'.

What adds to Tariq's troubles is that Hands Together's country head office in Dhaka has ordered the regional office in Sunamgonj to ensure that the distribution goes ahead without any glitches, despite the problem with the lists. This order came from Hands Together's main donor office in Europe. The European head office is answerable to its own national government and tax payers, and the international and corporate donors it receives funding from and (to a limited extent) the Bangladeshi government, but not to those that the policies affect the most. This draws attention to the uneasy fit of the multiple governing agencies, policies dreamed up in global cities and multinational institutions and practices that are rolled out on the ground in developing countries. Tariq says this sort of muddle happens frequently. As if to underscore the nervousness he feels, as we wait for a boat, Tariq receives a phone call from his staff still expecting us at the village. They have been sworn at by people whose names have been removed from the original list and who will no longer be receiving aid. With no alternative way of getting to the village, Tariq talks about turning back and cancelling the distribution. The recipients will have to go empty handed and the barge hired for the day to transport the corrugated tin will return to Sunamgonj, its cargo intact. This will mean added costs, which officials in Dhaka will complain about and the donor will disapprove of.

Suddenly, a tiny rowing boat appears on the horizon, steered by two soaking wet little boys who look like they are barely more than 10 years old. Despite my reluctance, I am persuaded that the journey to the village is not far. The boys eventually row up to the village; it is situated upon raised land in the middle of the water. The only pukka (concrete) building is the school, which also serves as the flood and cyclone shelter, occasional administrative office and now, relief distribution centre. Other than this, there is no physical presence of the state here. There is no electricity, bureaucracy or health facility. The select group of sixty or so villagers that are to receive aid have been waiting for us since day-break. By now it is mid afternoon. Nearly all are women (Karim 2011). They are skinny, possibly part of the proportion of the population who only have access to one or two meals a day. The men of the village who are of working age are either in the mines in India hewing coal, or in Bangladeshi Boropani labouring in the transportation end of the trade. Some able-bodied men have been called back to the village to help mothers and wives with the sheets of tin they will receive. Nonetheless, whilst the industry has invariably benefitted some, in particular those with previous connections to the Project, the liberalisation of the Bangladeshi and Indian economies has not financially or materially improved the lives of the majority of its workers.

21 Tariq begins the proceedings by impressing upon the villagers that his staff should be able to work in the area without being harassed. He looks slightly anxious but also 
extremely authoritative as he talks. Though only in his late twenties, his university degree and the backing of the foreign NGO give him confidence. The villagers refer to Tariq as 'officer', addressing him as 'sir'; terms of deference traditionally used to address government bureaucrats, illustrating how boundaries between the state and the NGO sector are blurred. Tariq is one of increasing numbers of bright and energetic young Bangladeshi graduates who, in recent years, have opted to work for the NGO sector; in an earlier period they would have hoped to work for the government. 'Hope' is the operative term here as public sector jobs were always limited and difficult to acquire without connections and/or leverage. There is a widespread perception that there are more opportunities and better pay and conditions working for NGOs (especially foreign ones), than within government employment. Nonetheless, public sector positions are still held in high regard despite (or perhaps because of) being associated with corruption, sloth, ineptitude and patronage. Tariq says he would prefer a stable, permanent government job, even with less pay, than a better paid NGO one. With flexible labour markets having emerged in all areas of work, he also has to re-apply every couple of years for his position and is hence unable to plan for the future in case he is made redundant. He says that he aims to make the switch to a government job once he has put in sufficient time working for Hands Together. It would be extremely difficult for him to get a government job had he not taken this route. ${ }^{9}$

One of Tariq's two staff members is a woman; she it is who the irritated villagers were particularly abusive towards. Her gender made her a soft target for their frustrations and allowed for comments and insults attacking her 'virtue'. 'She has come all the way from dry land to this wet land to help you. She doesn't need to do this' Tariq chastises the villagers. 'She is also someone's daughter, someone's wife. She should not have to hear bad things said about her.' He attempts to talk to some of the Group Representatives of the shomithi to appeal to what, he believes, are common gendered aims and sympathies. These are a handful of women from the village who have been elected by the rest of the shomithi to represent them in all matters relating to NAT's work. They have experience of labouring in the coal industry and with it, all its concomitant issues as working women. Having group representatives is not only pragmatic, but in the discourse of contemporary development they are part of an emerging social agenda which supposedly improves the public 'visibility' and status of women, encourages 'participation' and 'democratic decision-making' and contributes to wider 'community development' and 'empowerment'. ${ }^{10}$

Sharma \& Gupta (2006: 21) argue that initiatives such as group representatives attempt to teach people, in this case women, how to build their 'capacities' and become 'self dependent, responsible citizens who can take care of their own welfare and govern themselves'. In this moment and place, the success of the group representatives seems questionable. The women simply huddle next to one another on the bench allocated to them, not saying a word. They chew on the ends of their sarees in trepidation and seem very uncomfortable at being called to speak in public by Tariq. This is in particular because they may find themselves at odds either with their own neighbours or with the authority (and prospective resources) of the NGOs. The group representatives, it seems, do not consider the female development worker to be one of their own, or at the very least, one worth defending. Her education, class, job and language are more effective dividers than her gender is a unifier. These women seem a world away from those Rahman (1999: 95) writes about, members of the Grameen microcredit bank, who he says 
are 'more vocal and articulate compared to other women in the village who are not [...] members'. In fact, here, it is women not receiving and who have nothing to do with NAT and Hands Together's development work who are the most vocal in expressing their disapproval of the erasure of their neighbour's names from the list.

At this point, a self appointed village representative, a man with traditional capital as opposed to the group representatives who are, in effect, pretenders put forward by the $\mathrm{NGO}$, begins to shout about the lists. He is angry and demands to see the original, accusing Tariq and his staff of cheating the recipients. It becomes obvious that the villagers cannot or, rather, do not differentiate between the representatives of Hands Together and those of NAT whom they had, up until then, been dealing with. Tariq's two colleagues were previously employed by NAT. Furthermore, with the majority of the funding and project work that NAT does coming from Hands Together, all taking place conveniently under the banner of 'partnerships', the institutional separateness between the organisations is only notional. Is NAT a grassroots organisation? Is Hands Together an international organisation? Ferguson \& Gupta (2005: 117) argue that such entities not only do not fit easily within the 'state' versus 'civil society' grid, but also that they cannot easily be labelled 'local', 'national' or 'international'. They embody a significant local dynamic and are also at the same time a product and expression of powerful national, regional and global forces. The myth that they are independent is something that both NAT and Hands Together attempt to maintain, though it is at odds with everyday experiences, leading to the evident tensions.

Tariq warns me that the last thing he wants is to argue with the villagers, in particular because he fears that a physical altercation over the lists may be likely. He suspects that some of the people on the original list may have paid goosh (a bribe) to NAT representatives (not the two assistants) to be on it, hence they may be particularly cross at being struck off. The fee may have been a few hundred Taka (a few pounds), but nonetheless would still have been cheaper than buying tin on the open market. The practice of charging a fee for services that should be free for users is generally morally condemned in mainstream Bangladeshi society, but it is in fact extremely common when dealing with official government bureaucracies. In the borderlands this ranges from paying the border guards to sanction illegal mining in the border zone, to ensuring paperwork is processed by the Customs official. It is plainly a bureaucratic working practice that has seeped into the privatised realms, further collapsing the distinctions between the various governing agencies operating here and their behavioural practices. Tariq tries to take charge of the situation, telling the accuser that if he so wishes, he is welcome to go to the Hands Together office in Sunamgonj where they have copies of the first list. 'But for today, I have been instructed by my managers to distribute tin only to people whose names are on the second list' he says. The man responds that if he were to go to Sunamgonj, it would mean losing a second day's wages. He works as a coal labour leader in Boropani and has already lost income from having to stay in the village that day. Tariq says that Hands Together will refund his journey, if he can provide receipts for it. This is of course an underhand trick, a receipt being a commodity that no one in the borderlands deals with. The distribution finally begins, Tariq's efforts overcoming any nascent attempt at resistance against the NGO staff by aggrieved villagers.

Despite the villagers knowing the NGO staff, there is little trust between the givers and the receivers. The NGO staff are concerned that the villagers may simply storm the barge that contains the sheets of tin and walk off with them. The poor are inherently distrusted 
in this country of poor people. By this time I was accustomed to this and would experience it frequently and in a variety of ways. The poor are thought of as dishonest, dirty, carriers of disease and peddlers of social ills (perhaps not too dissimilar from how some international donors may view Bangladesh and the people of the 'Third World' generally, as the particular programmes directed at them show). It is not just amongst the wealthy and influential that this attitude is pervasive, but also amongst those of more modest means, as well as the 'poor' themselves. The 'NGO-wallahs' are on the whole, young, university educated men, ostensibly liberal, secular and open-minded individuals who put a high value on female education and emancipation. However, when it comes to ideas about the ghorib (the poor), their comments and ideas seem to hark back to a familiar colonial past. But rather than the topic of criticism being 'the natives', here it is their own countrymen. Fear and stereotypes intermingle with feelings of superiority and the burden of responsibility to 'civilise and develop' the unfortunate. Such attitudes among government-employed development workers were one of the things it was hoped that funding through NGOs would overcome. The fact that the shomithis they organise in the border region on the whole make a living not from agriculture and fishing (as the deserving poor do) but in the quasi-legal cross-border coal trade, intensifies this attitude. This is regardless of the fact that their organisations benefit financially from the regular micro-loan repayments made by coal labourers, with added bonuses and commissions. But instead of attempting to better the working and living conditions of their members, the development workers take a morally superior stance against those they work with.

Before the actual distribution can begin, Tariq makes a further announcement. Rather than receiving six sheets of tin, as previously pledged, everyone on the list will be getting five. Some complain, but these are desperate people, they are used to broken promises and disappointments. Tariq does not publically announce why this is, but he tells me later that it is because NAT, as well as having responsibility for drawing up the list of receivers, had been in charge of procurement. Senior members of the organisation embezzled funds and as a consequence fewer sheets were eventually bought. Added to this, the sheets were in fact second rate.

Tariq's colleagues have already handed out chits of paper to the recipients; these have the recipients' names and their father's names written on them. When a name is called out, the recipient goes to the table where Tariq's assistants match the chit to the official list. $\mathrm{S} /$ he then either signs or prints her/his thumb, indicating that they have received their sheets. They then show the ticket to Tariq who is standing on the barge and five sheets of tin are passed down. Older men and women are able to sign their names; not having held a pen in their hands for some time, their signatures are child-like scrawls, but nonetheless, they are able to sign. One woman, offended by the assertion that she may need the inkpad, states, 'I want the pen. I know how to write my own name'. Some youngsters, collecting on behalf of others, cannot do what the old woman is able to and stamp their thumbs. The difference between the two is indicative of a time not so long ago when it was believed that education would help people, and the nation itself, out of poverty: an aspect of the modernisation theory that has lost the sway that it once held. I am not suggesting that everyone used to know how to write their name; in fact the ledgers which recorded the workings of Khonighat show that the majority of labourers put thumb prints on payment sheets and did not sign. This of course does not indicate whether they were literate or not, but what it does reaffirm is that the benefits of modernisation were only for a few and not all. Furthermore, nationally, literacy rates and 
the numbers of children attending state schools, in particular girls, are on the rise today and this is something that is internationally recognised and praised.

Chits and sheets of tin are exchanged, counted and dispensed. There are constant complaints and grumbles from villagers. This seems to be the customary way of behaving towards authority, in the same way that it is Tariq's to look commanding and official. 'What is the point of five sheets of tin? You can't even build a toilet with five. You need eighteen in total to build a house' someone says. Another retaliates, 'when you go to a wedding, you don't expect to eat all the food, do you? So why complain so much?'. I meet a coal labourer in the throng. He has been called back from Boropani by his aged mother to help her with her allotted tin. He earns roughly 300 Taka (£3) per day by lugging coal sacks from the depot area to the river. Each sheet of tin costs 400 Taka ( $£ 4)$. What will you do with the tin? 'I will strengthen my house with them' he replies. 'Half of my mud house was washed away in the flood'. Tariq believes some of the recipients will go on to sell their donations. Despite NAT's chicanery, what is abundantly clear is that those who have been struck off the first list seem as poor and needy as those whose names are on the second list. By denying aid to those on the first list, Hands Together believes it is taking an explicit moral stance against what it labels 'corruption'. It expects to wipe clean such ingrained cultural and operational practices and exercise its own 'organisational culture' (Lewis 2003: 214).

In the classroom youngsters who have not been in one for a while although they are still the right age to be at school, commandeer the chalk and doodle on the blackboard. 'We don't go to school' they say, smiling, exposing iron eroded teeth. 'Can you read and write?' 'No' they say nervously. 'We work in Boropani as day labourers. We don't need to know how to read and write to do that'. They laugh. 'If you are not careful' I say, frustrated 'then soon, you too will be waiting in the rain for tin'. 'What are we to do, older brother? We have to eat and feed our families. If knowing how to read and write would do that, then of course we would. We are not stupid'. I watch people tend to their freshly cut wounds while arguments over the lists as well as the rain continues unabated.

More accusations and counter-accusations of corruption are hurled when a Member from the Union Parishad (council) arrives. His belated appearance in the village coincides with our preparations to leave. All the tin has been distributed. The Member is furious at Tariq for not consulting him before the distribution occurred, implying that as a publicly elected state official, his authority is greater and has been called into question. According to Tariq, the Member was told about it. The man conflates Hands Together and NAT, insinuating that the staff of both organisations have been cheating villagers. He plays on the increasingly generalised views of NGOs in Bangladesh as simply being interested in the material wellbeing of their staff and not the people they are supposed to be helping. This also draws attention to the practical knowledge of the multiplicity of governing agencies that the villagers have. They are willing to accept the resources of the NGOs, but when they feel aggrieved, turn to others within the conglomeration that produce statelike effects, even pitting one organisation against another. The Member threatens Tariq, telling him not to set foot in his constituency ever again. One is left thinking that if he is exemplary of the quality of representative democracy in Bangladesh, there is little doubt why the country's poor suffer so much. the only sign of relief is on the faces of Tariq and his staff, glad to be leaving the area. The villagers look as disgruntled and unsatisfied as when we arrived, their experience of the 
various governing agencies leaving them none the wiser as to what to do, or who to turn to next time an unexpected flash flood destroys their homes. Regardless of who or what the state is, and even in its multiple forms, it has abandoned these people, its citizens. The floods will return and simultaneously, a need and a tragedy for the people who live and work in the cross-border coal trade. The multiple governing agents will go through the motions, giving the impression that 'something is being done' to alleviate suffering (in the extreme cases) and 'development' is being carried forth for those who require it in the everyday sense. The system that causes poverty, alienation, exploitation or marginalisation is not tackled, the status quo remains unquestioned.

\section{Conclusion}

This paper has attempted to draw out how the state, in its current neoliberal avatar, has been reconfigured from its older, developmental paradigm, which involved large-scale infrastructural change and resource redistribution-aspects which many people continue to expect and associate with the primary workings of states. Using ethnographic evidence, I suggest that the state is now merely one of many other multiple governing agencies that participate in producing 'state-like effects' on a territory and its population. Local, national, and international NGOs, all with an assortment of agendas and loyalties, contribute to and produce 'state-like effects'. Other than for a short time in the postindependence period when there was ideological optimism to the contrary (when staterun installations such as the Khonighat Limestone Mining project existed), the idea of the centralised, sovereign Bangladeshi state from a fabled past being eroded by neoliberalism, is not a complete story. The people of the region have always co-existed alongside local, regional, and global entities. Nonetheless, how effective is the multiple agents' ability to bring about true and lasting transformations for the people who live and work in the coal trade on the Bangladesh-India border, remains to be seen.

\section{BIBLIOGRAPHY}

Alam, Shamsul S.M. (1995) The State, Class Formation and Development in Bangladesh, Lantham: University Press of America.

Aretxaga, Begona (2003) ‘Maddening States’, Annual Review of Anthropology 32, pp. 393-410.

Bayly, C.A. (1983) Rulers, Townsmen and Bazaars: North Indian Society in the Age of British Expansion 1770-1870, New Delhi: Oxford University Press, [2002].

Feldman, Shelly (1997) 'NGOs and Civil Society: (Un)stated Contradictions', ANNALS, American Association of Political and Social Science, 554, November, pp. 46-65.

Feldman, Shelly; McCarthy, Florence E. (1983) 'Purdah and Changing Patterns of Social Control Among Rural Women in Bangladesh', Journal of Marriage and the Family, 45(4), pp. 949-59. 
Ferguson, James (2006) Global Shadows: Africa in the Neoliberal World Order, Durham: Duke University Press.

Ferguson, James; Gupta, Akhil (2005) ‘Spatialising States: Toward an Ethnography of Neo-Liberal Governmentality', in Jonathan Xavier Inda (ed.), Anthropologies of Modernity: Foucault, Governmentality and Life Politics, Oxford: Blackwell Publishing, pp. 105-31.

Foucault, Michel (2006) 'Governmentality’ in Aradhana Sharma \& Akhil Gupta (ed.), The Anthropology of the State: A Reader, Oxford: Blackwell, pp. 131-43.

Hansen, Thomas Blom; Stepputat, Finn (eds.) (2005) Sovereign Bodies: Citizens, Migrants, and States in the Postcolonial World, Princeton: Princeton University Press.

Hussain, Delwar (2013) Boundaries Undermined: The Ruins of Progress on the Bangladesh-India Border, London: Hurst \& Co.

Karim, Lamia (2011) Microcredit and Its Discontents: Women in Debt in Bangladesh, Minnesota: University of Minnesota Press.

Kaviraj, Sudipta (2000) 'Modernity and Politics in India', Daedalus 129(1), pp. 137-62.

Khan, Mushtaq H. (2000) 'Class, Clientelism and Communal Politics in Contemporary Bangladesh', in K.N. Panikkar, Terence J. Byres \& Utsa Patnaik (eds.), The Making of History: Essays Presented to Irfan Habib, New Delhi: Tulika, pp. 572-606.

Lewis, David (2003) 'NGOs, Organization Culture, and Institutional Sustainability', Annals of the American Academy of Political and Social Science, 590, (Rethinking Sustainable Development), pp. $212-26$.

Lewis, David (2004) 'On the Difficulty of Studying 'Civil Society': Reflections on NGOs, State and Democracy in Bangladesh', Contributions to Indian Sociology, 38(2), pp. 299-322.

Lewis, David (2010) 'Exchanges of Professionals between the Public and Non-Governmental Sectors: Life-work Histories from Bangladesh', Modern Asian Studies, 45(3), pp.1-23.

Ong, Aihwa (2005) ‘Graduated Sovereignty in South East Asia', in Jonathan Xavier Inda (ed.), Anthropologies of Modernity: Foucault, Governmentality and Life Politics, Oxford: Blackwell Publishing, pp. 81-104.

Rahman, Aminur (1999) Women and Microcredit in Rural Bangladesh: Anthropological Study of the Rhetoric and Realities of Grameen Bank Lending, Colorado: Westview Press.

Roy, Beth (1994) Some Trouble with Cows: Making Sense of Social Conflict, Berkeley: University of California Press.

Sharma, Aradhana; Gupta, Akhil (ed.) (2006) The Anthropology of the State: A Reader, Oxford: Blackwell.

Sobhan, Rehman (1982) The Crisis of External Dependence: the Political Economy of Foreign Aid to Bangladesh, London: Zed Press.

Sobhan, Rehman (1997) 'The Political Economy of Micro Credit', in Geof Wood \& Iffath Sharif (eds.), Who Needs Credit? Poverty and Finance in Bangladesh, London: Zed Books, pp. 131-41.

Taylor, Marcus (2009) 'The Contradictions and Transformations of Neoliberalism in Latin America: From Structural Adjustment to "Empowering the Poor”, in Laura Macdonald \& Arne Ruckert (eds.), Post Neoliberalism in the Americas, London: Palgrave Macmillan, pp. 21-36. van Schendel, Willem (2009) A History of Bangladesh, Cambridge: Cambridge University Press. White, Sarah (1992) Arguing with the Crocodile: Gender and Class in Bangladesh, London: Zed Books. 
Wood, Geof (1997) 'States Without Citizens: The Problem of the Franchise State', in David Hulme \& David Edwards (eds.), NGOs, States and Donors: Too Close for Comfort ?, London: Macmillan Press, pp. 79-92.

\section{NOTES}

1. See also Hansen \& Stepputat (2005).

2. To protect informants, this and other names are all pseudonyms.

3. Other factors such as a massive cyclone, global financial meltdown due to the Oil crisis, the War of Independence and the withdrawal of Pakistani administrators contributed to this too.

4. Before 1971, foreign aid to East Pakistan amounted to $\$ 4$ per person. By the mid 1970 s it tripled, continuing to rise during the years of military rule until it reached an all time high of \$20 per Bangladeshi in 1990 (van Schendel 2009: 220). When the first Five Year Plan of the new country was published in 1973, it was projected that $39 \%$ of the total development investment would be made by foreign aid and by 1978, dependence on foreign aid would decrease to $27 \%$. However the Two Year Plan (1977-1979) found that $72 \%$ of total developmental investments came from foreign sources. During the Third Five Year Plan (1985-1990), the amount increased to 80\%. Foreign aid increased to $\$ 130$ million during the fiscal years 1985-1986 (Alam 1996: 93).

5. For more information about the Project, see Hussain 2013.

6. Interview by author, Boropani, 29 April 2009.

7. I am using a pseudonym for both NGOs to protect the identities of people

8. The region has recently become a site for much development work. The British Department for International Development, amongst other foreign countries, is funding a number of community-based organisations who all work in the wetlands.

9. Lewis (2010) also finds that the boundaries between government, business, and civil society are extremely ambiguous but nonetheless they continue to be constructed and maintained by the agents themselves, as well as by those on the receiving end of their resources and services.

10. See Feldman and E. McCarthy (1983) for further discussion.

\section{ABSTRACTS}

By focusing on a remote part of the Bangladesh-India border, this paper seeks to understand how the state has been reconfigured from its older, developmental paradigm, involving large-scale infrastructural change and resource redistribution, to its contemporary NGO-driven avatar. The paper suggests that the state today is merely one of multiple governing agencies that participate in producing 'state-like effects' on a territory and its population. Sometimes these agencies are in competition; often they work alongside one another. NGOs are agencies of this kind and are a major focus of this paper. In light of this, the idea of a sovereign Bangladeshi state which is apparently being eroded by neoliberalism, is not a complete picture. Other than a particular moment in the post-colonial period where there was optimism that the contrary would be achieved, sovereignty has in fact always been a mediated, fragmented affair in the borderlands as well as in Bangladesh as a whole. 
INDEX

Keywords: border, state, NGO, development, corruption

\section{AUTHOR}

DELWAR HUSSAIN

Chancellor's Fellow in Social Anthropology, University of Edinburgh 